Tersedia Online di http://journal2.um.ac.id/index.php/jmsp/

ISSN Online : 2541-4429

\title{
HAMBATAN IMPLEMENTASI PROGRAM KERJA KOMITE SEKOLAH UNTUK MENINGKATKAN PERAN SERTA MASYARAKAT
}

\author{
Teguh Triwiyanto \\ Fakultas Ilmu Pendidikan Universitas Negeri Malang \\ Jl. Semarang 5 Kota Malang Jawa Timur Indonesia \\ teguh.triwiyanto.fip@um.ac.id
}

\begin{abstract}
The objective of this research is to know the obstacles of implementation of work program of school committee to increase community participation in education. This research uses qualitative design, research involving supervisors, principals, school committees and teachers of 56 people from 34 provinces in Indonesia. Data were collected through observation, documentation, in-depth interviews, and group discussion forums. This data analysis is done in the research process, done intensively during the field, and after leaving the field. Final analysis, ie after all the required data are collected or after the end of the field research period. The results of the research indicate that there are several obstacles to the implementation of school committee work program to increase community participation in education
\end{abstract}

Keywords: work program, school committee, community participation

\begin{abstract}
Abstrak: Penelitian ini untuk mengetahui hambatan implementasi program kerja komite sekolah untuk meningkatkan peran serta masyarakat dalam pendidikan. Penelitian ini menggunakan desain kualitatif, penelitian melibatkan pengawas, kepala sekolah, komite sekolah dan guru sebanyak 56 orang dari 34 provinsi di Indonesia. Data dikumpulkan melalui observasi, dokumentasi, wawancara mendalam, dan forum group discussion. Analisis data ini dilakukan dalam proses penelitian, dikerjakan secara intensif selama di lapangan, dan setelah meninggalkan lapangan. Analisis akhir, yaitu setelah semua data-data yang dibutuhkan terkumpul atau setelah berakhirnya masa-masa penelitian lapangan. Hasil penelitian menunjukkan adanya beberapa hambatan implementasi program kerja komite sekolah untuk meningkatkan peran serta masyarakat dalam pendidikan.
\end{abstract}

Kata kunci: program kerja, komite sekolah, peran serta masyarakat

Komite sekolah sebagai badan mandiri yang mewadahi peran serta masyarakat dalam rangka meningkatkan mutu, pemerataan, dan efisiensi pengelolaan pendidikan di satuan pendidikan, idealnya memiliki program kerja untuk menuntun aktivitasnya. Manajemen sekolah merupakan balikan yang tercermin dalam bentuk tindakan dan perilaku kepala sekolah dalam hal otonomi, kemitraan dan partisipatif proses pengambilan keputusan, meningkatkan kualitas pendidikan, struktur organisasi dan partisipasi dalam pengambilan keputusan pada satuan pendidikan (Bandur, 2012:316; Solomou, Nicolaidou, dan Petros, 2016:718; Chann, 2016:131; Jeong, Lee, Cho, 2017:12; Arar dan Romi, 2016:191).
Program kerja merupakan kanalisasi kebutuhan peran serta masyarakat, pendidikan, kepala sekolah menjadi manajer dalam pengelolaan sekolah. Perilaku kepala sekolah sebagai penanggung jawab manajemen, walaupun ada kebijakan sebagai payungnya sering berbeda pendekatan dalam menyikapi komite sekolah. Angelle (2017:5) menyatakan bahwa kepala sekolah menyatakan keyakinan yang sama tentang masyarakat, tetapi pendekatan perilaku berbeda dalam pelaksanaannya.

Program kerja komite sekolah untuk mewadahi dan menyalurkan aspirasi dan prakarsa masyarakat dalam melahirkan kebijakan operasional dan program pendidikan di satuan 
pendidikan, menjadi sandungan karena peran vitalnya tersebut tidak diadakan. Walaupun tentu saja program kerja bukan segalanya, tetapi akuntabilitas dapat dirunut melaluinya, sebab wujud kolaboratif sekolah dan masyarakat tercermin dari program komite sekolah. Hasil penelitian Agbo (2007:1) menunjukkan bahwa hubungan sekolah-masyarakat kolaboratif untuk berkembang di masyarakat, sekolah harus memberdayakan masyarakat melalui diskusi yang tulus bahwa kolaborasi membimbing dan menghormati antarwarga sekolah dalam berbagai perspektif.

Hubungan sekolah-masyarakat kolaboratif untuk memperkuat citra sekolah melalui program kerja komite sekolah, melibatkan masyarakat dalam penyusunannya. Citra sekolah memberikan gambaran berkesan yang kuat pada seseorang atau masyarakat orang mengenai sekolah, tentu saja yang dibangun citra positif. Citra sekolah merupakan gambaran yang dimiliki oleh seseorang atau masyarakat mengenai pribadi dan organisasi sekolah, tentu saja yang dimaksudkan citra positif yang datang. Frank (2007:350) menyatakan bahwa tekanan mempromosikan citra sekolah dalam rangka untuk menarik siswa telah memaksa sekolah untuk berubah dari sikap terpisah mereka terhadap masyarakat, untuk ke arah bagaimana mengembangkan hubungan yang produktif dengan itu.

Hambatan kinerja komite sekolah dapat dilacak dari hasil-hasil penelitian sebelumnya, peran komite sekolah, kondisi lingkungan pendukung, dan pengelolaan sumber daya. Hasil penelitian Hanafi dan Ma'sum (2015:58) menunjukkan bahwa pada hampir semua peran komite sekolah, peran pengawasan paling lemah diantara peran lainnya. Peran komite kurang optimal disebabkan karena beragamnya kondisi lingkungan sekolah dan bervariasinya kebutuhan siswa di dalam proses pembelajaran ditambah lagi dengan kondisi geografi Indonesia yang sangat kompleks, seringkali tidak dapat diapresiasikan secara lengkap oleh birokrasi pusat (Cahyana, 2010:109). Hasil penelitian Daud (2015:693) menyatakan bahwa semakin efektif kepala sekolah memainkan perannya, semakin efektif visi dan misi sekolah diimplementasikan dan lebih efisien manajemen sumber daya sekolah.

Sumber daya sekolah terkait erat dengan kebijakan pendidikan yang dikeluarkan pemerintah di satu sisi, dan masyarakat pada sisi lainnya. Kebijakan pemerintah berupa standar nasional pendidikan, standar pengelolaan dan penyelenggaraan, isi, proses, pengelolaan, penilaian, sarana prasarana, pendidik dan tenaga kependidikan, dan pembiayaan menjadi garis batas penyelenggaaran yang baik untuk masyarakat. Untuk memenuhi standar pendidikan tersebut, sekolah melalui peran serta masyarakat dapat mengupayakan untuk mencapai tujuaan pendidikan secara efektif dan efisien. Peran serta masyarakat dapat berupa dukungan tenaga, pikiran, dan sumber daya lain bagi kepentingan pendidikan. Peran serta masyarakat merupakan upaya menggali potensi masyarakat sekolah, baik dari dalam (guru, staf, dan siswa) maupun dari luar (orang tua, masyarakat, dunia usaha dan dunia industri). Memang peran serta masyarakat terjadi pada semua standar yang ada, Arismunandar (2013) menyatakan bahwa terdapat kecenderungan umum peran serta masyarakat dalam kurikulum lebih didominasi oleh orang tua daripada kelompok lainnya. Peran serta masyarakat dalam kurikulum lebih menonjol dalam pengembangan kurikulum muatan lokal dan kurang menonjol dalam program pengayaan dan remedial.

Berdasarkan kajian pendahuluan tersebut, tujuan penelitian ini untuk mengetahui hambatan implementasi program kerja komite sekolah untuk meningkatkan peran serta masyarakat dalam pendidikan, dikemukakan juga saran pada bagian akhir penelitian ini terkait dengan implementasi program kerja komite sekolah.

\section{METODE}

Penelitian ini menggunakan desain kualitatif, penelitian melibatkan pengawas, kepala sekolah, komite sekolah dan guru sebanyak 56 orang dari 34 provinsi di Indonesia. Data dikumpulkan melalui observasi, dokumentasi, wawancara mendalam, dan forum group discussion. Analisis data ini dilakukan dalam proses penelitian, dikerjakan secara intensif selama di lapangan, dan setelah meninggalkan lapangan. Analisis akhir, yaitu setelah semua data-data yang dibutuhkan terkumpul atau setelah berakhirnya masa-masa penelitian lapangan. Peneliti melukiskan dan menafsirkan data yang ada, sehingga pekerjaan penulis menjelaskan proses yang terjadi, 
menyatakan baik atau tidak, menjelaskan keunggulan dan kelemahannya, dan sesuai atau tidaknya proses yang dilakukan dengan prinsipprinsip umum yang berlaku.

Supaya keabsahan data dalam penelitian kualitatif ini benar-benar baik dan terpercaya, maka dilakukan pengecekan keabsahan data yang didasarkan pada kriteria tertentu sebagaimana yang disarankan Lincoln dan Guba (2002:300) yaitu keterpercayaan, keteralihan, ketergantungan, dan kepastian.

\section{HASIL DAN PEMBAHASAN}

\section{Hasil}

Hasil peneilitan menunjukkan bahwa hambatan implementasi program kerja komite sekolah untuk meningkatkan peran serta masyarakat dalam pendidikan di Indonesia terhambat karena: (1) program kerja komite sekolah yang sudah ada, tetapi kriteria program belum sesuai dengan apa yang diharapkan, sehingga perlu kriteria program komite sekolah yang jelas; (2) sosialisasi mengenai program kerja komite sekolah masih minim dilakukan; (3) rata-rata anggota komite sekolah memiliki latar belakang pendidikannya rendah, sehingga perlu bimbingan dan pelatihan; (4) struktur komite belum semuanya ada, apalagi programnya, diperlukan pendampingan untuk komite sekolah; (5) pembentukan komite hanya sekedar menggugurkan kewajiban, perencanaan hanya pada kehendak kepala sekolah, keberagaman jenis sekolah menjadikan persoalan tiap sekolah berbeda dan perlu penanganan berbeda; dan (6) adanya pandangan tentang fungsi komite yang tidak diperlukan lagi karena sekolah sudah gratis, komite hanya berbicara tentang uang, sekolah dan komite memiliki cara sendiri dalam mengelola lembaganya sehingga pembinaan sulit dilakukan.

\section{Pembahasan}

Program kerja komite sekolah merupakan kompromi, kalau bukan tarik-menarik, sekolah dan masyarakat sebagai stakeholder pendidikan. Ia menjelma sekaligus kanalisasi berbagai kepentingan dan harapan masyarakat terhadap mutu proses dan mutu hasil pembelajaran, yang tercermin dari penguasaan kompetensi siswanya. Hasil penelitian ini memperlihatkan program kerja komite sekolah sudah ada, tetapi kriteria program belum sesuai dengan apa yang diharapkan, sehingga perlu kriteria program komite sekolah yang jelas. Program kerja komite sekolah dalam implementasi menjadi sulit untuk menilai hasil karena kriteria tidak tersedia, termasuk upaya melaksanakan kegiatan dengan melibatkan peran serta masyarakat yang masih lemah. Darinskaya, Moskvicheva, dan Molodtsova (2015:569) menyatakan program kerja dapat dilaksanakan kurang baik terletak pada komunikasi yang lemah, terutama pada rendahnya tingkat refleksi konfirmasi. Din, Anuar, dan Usman (2016:117) temuan penelitiannya menunjukkan hubungan yang kuat antara rencana kegiatan, berpikir risiko dan juga self-efficacy dan efektivitas program, sementara hubungan moderat terlihat dalam kebutuhan untuk berprestasi dan lokus kontrol.

Kanal sekolah dan masyarakat berupa program kerja komite menjadi kurang efektif dilaksanakan jika dari awal perencanaannya minim melibatkan dialog diantara keduanya. Rasa memiliki dan melaksanakan program kerja dapat tercapai jika ada keterlibatan masing-masing unsur komite dalam merencanakan. Keberhasilan perencanaan menuntut peran serta aktif dari seluruh warga sekolah dan dukungan dari warga masyarakat. Seluruh komponen sekolah harus mempunyai persepsi yang sama dalam menguatkan seluruh progam yang dijalankan menuju pencapaian visi dan misi sekolah.

Hubungan kuat implementasi program kerja dengan aspek lainnya menjadi penentu daya efektifitas capaiannya. Aspek-aspek yang berpengaruh terhadap keberhasilan program kerja komite sekolah perlu mendapat perhatian serius, bukan sekedar administratif dan prosedural yang biasanya diadakan untuk bukti fisik akreditasi. Udou, Grover, Belcher, dan Kacirek (2017:106) menyatakan program pendidikan musti memiliki dukungan kualitas program, yang dibuktikan dengan misi yang jelas dan peran dalam masyarakat, sistem manajemen, manajemen sumber daya manusia, dan kontekstual dengan masyarakat. Ingemarson, Rubenson, Bodin, dan Guldbrandsson (2014:48) menyatakan bahwa kepemimpinan, pembinaan dan seleksi staf perlu perhatian khusus ketika melaksanakan program, karena faktor-faktor tersebut telah didefinisikan sebagai pengendali implementasi yang penting.

Pengendalian implementasi program kerja 
komite sekolah terletak pada kepemimipnan yang mampu mengelola sumber daya yang ada dengan baik. Kepemimpinan komite sekolah, sering diabaikan dalam kajian sekolah, alihalih kepemimpian kepala sekolah dan program kerjanya yang berkutat pada tema-tema tertentu. Hasil penelitian Hallinger (2011:125) menyatakan bahwa selama 40 tahun terakhir penelitian empirik mengenai kerja sekolah hanya berkutat pada tema-tema berikut: kepala sekolah dan kepemimpinan, kepala sekolah penting, tapi untuk sukses perlu dorongan untuk kerja sama, membangun kepemimpinan membutuhkan kapasitas perubahan, pemahaman yang kontekstual dan kepemimpinan strategis, dan pemberdayaan kepemimpinan dan lingkungan melalui waktu dan metode yang tepat.

Komite sekolah di Indonesia perlu diperdayakan melalui implementasi program kerja dan pelibatan masyarakat, mitra kepala sekolah sebagi pemberi pertimbangan penentuan dan pelaksanaan kebijakan pendidikan di sekolah, pendukung baik yang berwujud finansial, pemikiran maupun tenaga dalam penyelenggaraan pendidikan di sekolah, pengontrol dalam rangka transparansi dan akuntabilitas penyelenggaraan dan keluaran pendidikan di sekolah, dan mediator antara pemerintah dengan masyarakat di sekolah. Posisi strategis komite sekolah tersebut perlu ditopang sumber daya yang memadai, kepala sekolah dapat memberikan karena penguasaan memadai terkait manajemen sekolah yang menjadi tanggung jawab sehari-hari. Program kerja komite sekolah mendukung program kerja kepala sekolah, begitu sebaliknya, untuk mencapai efektifitas dan efisiensi mencapai tujuan pendidikan. Hasil penelitian Hanafi dan Ma'sum (2015:58) menunjukkan bahwa secara keseluruhan peran komite sekolah masih cukup tinggi, kecuali peran pengawasan, dan peran mediasi antara sekolah dengan dunia kerja dan industri relatif rendah.

Untuk menuju terealisasinya program kerja komite sekolah, dibutuhkan perangkat pengetahuan yang memadai dari pemangku kepentingan di sekolah dan masyarakat, dibutuhkan sosialisasi masif untuk itu. Hasil penelitian ini memperlihatkan sosialisasi mengenai program kerja komite sekolah masih minim dilakukan di Indonesia. Pengaturan melalui sosialisasi awal meningkatkan keberhasilan program kerja (Park dan Zhan, 2017:230), keterlibatan ayah cenderung memiliki hasil yang lebih positif untuk kesehatan emosional fisik, kognitif, dan sosial siswa (Campbell, Howard, Rayford, dan Gordon (2015:84). Untuk menumbuhkan kesadaran untuk keberhasilan program kerja dan keterlibatan masyarakat dibutuhkan sosialisasi dengan media memadai, beragamnya latar belakang pendidikan orang tua dan masyarakat menjadi tantangan tersendiri.

Hasil penelitian ini memperlihatkan ratarata anggota komite sekolah memiliki latar belakang pendidikannya rendah, sehingga perlu bimbingan dan pelatihan. Penelitian Wixe dan Andersson (2017:623) menunjukkan bahwa pekerjaan dan pendidikan berkorelasi positif dengan pertumbuhan produktivitas. Praktik pemimpin sekolah membantu orang tua untuk mendukung keberhasilan anak-anak mereka di sekolah (Jeynes, 2017:311). Hubungan antara kegiatan keaksaraan orang tua dengan anak, status sosial-ekonomi, dan melek membaca (Hemmerechts, 2017:85). Latar belakang pendidikan ini menjadi modal pengetahuan yang menentukan cara pandang, sikap, dan perilaku terhadap keberadaan program kerja komite sekolah. Selain hal tersebut, terdapat juga aspekaspek yang memengaruhi aktivitas anggota dalam menjalankan program kerja komite sekolah, yang sifatnya cenderung eksternal, dalam pembentukannya menjadi bagian yang melekat pada individu. Aspek-aspek tersebut antara lain kematangan intelektual, kemampuan berbahasa, latar belakang pengalaman, cara atau gaya dalam mempelajari sesuatu, bakat dan minat, serta kepribadian.

Selain latar belakang pendidikan yang rendah, implementasi program kerja komite sekolah juga membutuhkan kejelasan informasi, konsistensi informasi, ketersediaan sumberdaya, sikap dan komitmen dari pelaksana, dan struktur birokrasi yang mengatur tata laksana. Hasil penelitian ini memperlihatkan struktur komite di Indonesia belum semuanya ada, apalagi programnya, diperlukan pendampingan untuk komite sekolah.

Hasil penelitian ini juga menunjukkan bahwa ada anggapan pembentukan komite hanya sekedar menggugurkan kewajiban, perencanaan hanya pada kehendak kepala sekolah, keberagaman jenis sekolah menjadikan persoalan tiap 
sekolah berbeda dan perlu penanganan berbeda. Padahal, mestinya pembentukan komite sekolah mewujudkan adanya suatu organisasi "masyarakat sekolah" yang mempunyai komitmen, loyalitas, dan peduli terhadap peningkatan mutu pendidikan. Yani, (2013:175) menunjukkan faktor kurang efektifnya pembentukan komite sekolah karena: (1) kurangnya komunikasi dan sosialisasi kepada masyarakat, orang tua/wali siswa, dan stakeholder lainnya mengenai peran dan fungsi komite sekolah, (2) komite sampai saat ini belum didukung perangkat organisasi lain seperti anggaran dasar/anggaran rumah tangga dan ruang kerja, dan (3) kesibukan pengurus yang sebagian besar bekerja di tempat lain.

Masyarakat sekolah yang mewujud pada komite sekolah membutuhkan adaptasi terhadap perubahan ekosistem pendidikan. Bahwa komite sekolah membutuhkan evolusi teori organisasi kontemporer, pada saat ini organisasi membutuhkan cara pandang sistem terbuka, perspektif tujuan sosial, tema utama kekuasaan dan politik yang melingkupinya. Evolusi tersebut terjadi dalam kerangka waktu, tema-tema yang mendasari, berdasarkan tipe sekolah yang yang memiliki karakteristik berbeda. Sekolah yang masih memiliki nuansa tertutup, rasional, dan efisien memang tampak tertinggal. Sekolah dengan kerangka evolusi ini akan baik jika perspektif sistemnya terbuka dengan perspektif tujuannya sosial, sementara kekuasaan dan politik merupakan tempat kebijakan-kebijakan di produksi. Di sekolah kebijakan dibuat oleh kepala sekolah sebagai pejabat tertingginya.

Menurut Purwanto (2009:160) sistem persekolahan di Indonesia pada umumnya kepala sekolah merupakan jabatan yang tertinggi di sekolah sehingga dengan demikian kepala sekolah memegang peranan dan pimpinan segala sesuatu yang berhubungan dengan tugas sekolah ke dalam maupun ke luar. Maka dari itu, dalam struktur organisasi sekolah pun kepala sekolah biasanya selalu didudukkan di tempat paling atas. Faktor yang menyebabkan organisasi sekolah perlu baik yaitu karena tugas pendidik tidak hanya mengajar dan mendidik saja, semuanya harus bertanggung jawab dan diikutsertakan dalam menjalankan roda sekolah secara keseluruhan. Dengan demikian agar tidak tumpang tindih dalam memegang dan menjalankan tugasnya masing-masing, diperlukan organisasi sekolah yang baik dan teratur. Zapeda, Bengtson, dan Parylo (2012:136) dari hasil penelitiannya menemukan bahwa perencanaan yang baik dan kepemimpinan kepala sekolah signifikan dan penting dalam membentuk performance sekolah. Peraturan Menteri Pendidikan dan Kebudayaan Nomor 75 tahun 2016, menegaskan bahwa, komite sekolah berfungsi dalam peningkatan mutu pelayanan pendidikan.

Karena pentingnya faktor kepala sekolah ini, maka diperlukan figur dengan kapasitas memadai, kompetensi untuk mengelola hubungan sekolah dan masyarakat dalam rangka pencarian dukungan gagasan, sumber belajar, dan pembiayaan sekolah. Selain itu diperlukan kemampuan kepala sekolah untuk mengelola perubahan dan pengembangan sekolah menuju organisasi pembelajar yang efektif. Kepala sekolah dituntut mampu menjalan fungsi hubungan dengan masyarakat dengan baik, menurut Kowalski (2004:11) hubungan sekolah dan masyarakat tersebut untuk mengoptimalkan: (1) improving the quality of education; (2) encouraging open political communication; (3) enhacing the image of the school or district; (4) building support for change; (5) managing information; (6) marketing program; (7) establishing goodwill and a sense of ownership; and (8) providing evaluation data.

Hasil penelitian ini menunjukkan adanya pandangan tentang fungsi komite yang tidak diperlukan lagi karena sekolah sudah gratis, komite hanya berbicara tentang uang, sekolah dan komite memiliki cara sendiri dalam mengelola lembaganya sehingga pembinaan sulit dilakukan. Konstruksi masyarakat terhadap komite sekolah seperti itu beralasan, sebab sejarah komite sebagai stempel sekolah, atau kepala sekolah, untuk menarik biaya pendidikan dari masyarakat kental pada masanya. Pembangunan fasilitas pendidikan banyak dialirkan melalui komite sekolah ini, steorotype itu melekat, sehingga pada saat pendidikan dasar pembiayaannya diambil alih pemerintah masyarakat mempertanyakan fungsi komite sekolah. Keberadaan program kerja komite bertumpu pada peran serta masyarakat untuk meningkatkan kualitas layanan sekolah, oleh karena itu komite perlu memiliki peran yang jelas sesuai dengan posisinya. Peran komite sekolah bukan hanya terbatas pada mobilisasi sumbangan, tetapi lebih pokok untuk membantu dan mengawasi pelaksanaan program sekolah. 
Di Indonesia, manajemen berbasis sekolah yang dimplementasi di lapangan ditandai dengan pembentukan komite sekolah dimana peranan yang ditonjolkan adalah fungsi pencarian dana untuk mengganti genteng yang bocor atau tembok yangrusak, tampak padaiklan sosialisasi ditelevisi saat menjelang pembentukan komite sekolah tahun 2002. Sekolah yang memiliki perangkat, struktur, dan pembagian tugas pengelola dan komite sekolah, tetapi kinerja mereka tidak mencerminkan realitas dan menjawab kebutuhan masyarakat. Praktik manajemen berbasis sekolah hanya pada membuat perangkat yang dibutuhkan, pembentukan komite sekolah peran serta masyarakat banyak pada penyediaan infrastruktur sekolah. Semangat demokratisasi, otonomi, dan pengambilan keputusan secara mandiri oleh sekolah dalam manajemen berbasis sekolah masih lemah.

Belajar dari negara lain, lingkup peran komite di Indonesia kurang optimal, perlu dilakukan reformasi karena sikap masyarakat dalam memandang mutu pendidikan. Hasil penelitian Ganimian (2016:33) tahun 1990an, El Salvador, Nikaragua, Guatemala, dan Honduras diberlakukan bentuk reformasi yang memungkinkan masyarakat untuk membuat keputusan penting tentang sekolah mereka, yang sebelumnya disediakan untuk pejabat negara yang ditunjuk. Kwan, Cheung, Law, Cheung, S.G., Shin, (2017:53) menyatakan bahwa pelaksanaan inisiatif program pendidikan publik berbasis lokal sulit dilaksanakan karena sikap apatis tertanam di masyarakat Asia. Temuan penelitian Taniguchi dan Hirakawa (2016:479) bahwa manajemen sekolah di banyak negara Afrika sub-Sahara telah ditingkatkan melalui peran serta masyarakat dalam upaya untuk meningkatkan mutu pendidikan.

\section{KESIMPULAN DAN SARAN}

\section{Kesimpulan}

Hambatan implementasi program kerja komite sekolah untuk meningkatkan peran serta masyarakat dalam pendidikan terhambat karena: (1) program kerja komite sekolah yang sudah ada, tetapi kriteria program belum sesuai apa yang diharapkan, sehingga perlu kriteria program komite sekolah yang jelas; (2) sosialisasi mengenai program kerja komite sekolah masih minim dilakukan; (3) rata-rata anggota komite sekolah memiliki latar belakang pendidikannya rendah, sehingga perlu bimbingan dan pelatihan; (4) struktur komite belum semuanya ada, apa lagi programnya, di perlukan pendampingan untuk komite sekolah; (5) pembentukan komite hanya sekedar menggugurkan kewajiban, perencanaan hanya pada kehendak kepala sekolah, keberagaman jenis sekolah menjadikan persoalan tiap sekolah berbeda dan perlu penanganan berbeda; dan (6) adanya pandangan tentang fungsi komite yang tidak diperlukan lagi karena sekolah sudah gratis, komite hanya berbicara tentang uang, sekolah dan komite memiliki cara sendiri dalam mengelola lembaganya sehingga pembinaan sulit dilakukan.

\section{Saran}

Saran untuk mengurangi hambatan komite sekolah untuk memiliki program kerja yaitu: (1) perlunya petunjuk teknis pembuatan program kerja untuk komite sekolah; (2) perlunya program yang utuh dapat menyentuh sampai pada kebutuhan sekolah,dan masyarakat, bukan sekedar pada level provinsi saja; (3) perlunya anjuran dari kementerian pendidikan, dinas pendidikan provinsi berupa surat untuk melaksanakan program kerja dengan peran serta masyarakat di daerah; (4) perlunya monitoring dan evaluasi sebagai kontrol kegiatan program komite sekolah; (5) pengawas perlu mendampingi komite sekolah untuk membuat program kerja; (6) perlunya dilakukan pelatihan bagi komite sekolah di masing-masing daerah untuk meningkatkan program kerja komite sekolah; (7) perlunya dibangun komunikasi yang harmonis antara pengurus komite dan pihak sekolah; dan (8) perlunya rembug gugus (mengundang kepala sekolah dan komite) dengan tema peran serta masyarakat.

\section{DAFTAR RUJUKAN}

Agbo, S.A. 2007. Addressing School-Community Relations in a Cross-Cultural Context: A Collaborative Action to Bridge the Gap between First Nations and the School. Journal of Research in Rural Education. 22 (8): 1-14.

Angelle, P.S. 2017. Beliefs and Behaviors of Two High School Principals in Developing a Sense of School Community for Students. Health 
Education. 101(1): 5-22.

Arar, K., Romi, A.A. 2016. School-Based Management: Arab Education System in Israel. Journal of Educational Administration. 54 (2):191-208.

Arismunandar. 2013. Peran Serta Masyarakat Melalui MBS dalam Menyukseskan Kurikulum 2013. Disajikan pada Seminar Evaluasi dan Program Tindak Lanjut Bimtek MBS di SD, Hotel Golden Tulip Galaxy, Banjarmasin, 29 Oktober sd. 1 November 2014

Bandur, A. 2012. School-Based Management Developments and Partnership: Evidence from Indonesia. International Journal of Educational Development. 32 (2): 316-328.

Cahyana, A. 2010. Upaya Peningkatan Mutu Sekolah Melalui Satuan Otonomi Pendidikan. Jurnal Pendidikan dan Kebudayaan. 16 (2):109-117.

Campbell, C.A., Howard, D., Rayford, B S., Gordon, D.M. 2015. Fathers Matter: Involving and Engaging Fathers in the Child Welfare System Process. Children and Youth Services Review. 53 (6): 84-91.

Chann, A. 2016. Popularity of the Decentralization Reform and Its Effects on the Quality of Education. Prospects Comparative Journal of Curriculum, Learning, and Assessment. 46 (1):131-147.

Darinskaya, L., Moskvicheva, N., Molodtsova, G. 2015. Training Program as a Means of Improving Effectiveness of Pedagogical Communication. Procedia - Social and Behavioral Sciences. 171 (16): 569-575.

Daud, K. 2015. The Implementation of School Based Management Policy: An Exploration. Procedia - Social and Behavioral Sciences. 172 (1):693700.

Din, B., Anuar, A.R., Usman, M. 2016. The Effectiveness of the Entrepreneurship Education Program in Upgrading Entrepreneurial Skills among Public University Students. Procedia Social and Behavioral Sciences. 224 (15): 117123.

Frank, W.T. 2007. Rethinking School and Community Relations in Hong Kong. International Journal of Educational Management. 21 (4:350-366.

Ganimian, A.J. 2016. Why Do Some School-Based Management Reforms Survive While Others Are Reversed? The cases of Honduras and Guatemala. International Journal of Educational Development. 47 (3):33-46.

Hallinger,P.2011. Leadership for Learning: Lesson from 40 years of Empirical Reseacrh. Journal of Educational Administration, 49 (2):125-134.

Hanafi, I., Ma'sum, M. 2015. Analisis Implementasi
Kebijakan Pendidikan: Peran Komite Sekolah Pada Sekolah Menengah Kejuruan. Cakrawala Pendidikan Jurnal Ilmiah Pendidikan. XXXIV (1):58-66.

Hanafi, I., Ma'sum, M. 2015. Analisis Implementasi Kebijakan Pendidikan: Peran Komite Sekolah pada Sekolah Menengah Kejuruan. Cakrawala Pendidikan Jurnal Ilmiah Pendidikan, XXXIV (1):58-66.

Hemmerechts, K. 2017. Educational the Relationship Between Parental Literacy Involvement, Socio-Economic Status And Reading Literacy. Educational Review. 69 (1): 85-101.

Ingemarson, M., Rubenson, B., Bodin, M., Guldbrandsson, K. 2014. Implementation of A School-Wide Prevention Programme-Teachers' And Headmasters' Perceptions of Organizational Capacity. Evaluation and Program Planning. 43 (4): 48-54.

Jeong, D.W., Lee, H.J., Cho, S.K. 2017. Education Decentralization, School Resources, and Student Outcomes in Korea. International Journal of Educational Development. 53 (3):12-27.

Jeynes, W. H. 2017. Effects of Family Educational Cultures on Student Success at School: Directions for Leadership. Studies in Educational Leadership. 23 (1): 311-328.

Kowalski, T.J. 2004. Public Relations in Schools. New Jersey: Pearson Education, Inc.

Kwan, B K.Y., Cheung, J H.Y., Law, A.C.K., Cheung, S.G., Shin, P. K.S. 2017. Conservation Education Program for Threatened Asian Horseshoe Crabs: A Step towards Reducing Community Apathy to Environmental Conservation. Journal for Nature Conservation. 35(2): 53-65.

Lincoln, Y.S., Guba, E.G.L. 2002. Naturalistic Inquiry. 4th Edition. Beverly Hill, CA: SAGE Publication, INC.

Park, H., Zhan, M. 2017. The Impact of After-School Childcare Arrangements on the Developmental Outcomes of Low-Income Children. Children and Youth Services Review. 73 (1): 230 - 241.

Peraturan Menteri Pendidikan dan Kebudayaan Nomor 75 Tahun 2016 tentang Komite Sekolah.

Purwanto, N. 2009. Administrasi dan Supervisi Pendidikan. Bandung: Remaja Rosdakarya.

Solomou, Nicolaidou, G., Petros, P. 2016. An Effective School Autonomy Model. The International Journal of Educational Management. 30 (5): 718734.

Taniguchi, K., Hirakawa, Y. 2016. Dynamics of Community Participation, Student Achievement and School Management: The Case of Primary Schools in a Rural Area of Malawi. Compare: A Journal of Comparative and International 
Education. 46 (3): 479-502.

Udou, G.J., Grover, K., Belcher, G., Kacirek, K. 2017. An Investigation of Perceptions of Programme Quality Support of Adult Basic Education Programmes. Evaluation and Program Planning. 61 (4): 106-112.

Wixe, S., Andersson, M. 2017. Which Types Of Relatedness Matter In Regional Growth? Industry. Occupation and Education. 51 (4): 523536.

Yani, Ahmad. 2013. Peran Komite Sekolah Di Sekolah Menengah Pertama Islam Terpadu Al-Fityan Gowa. Akmen Jurnal Ilmiah. 10 (2): 175-184.

Zapeda, S.J., Bengtson, Ed., and Parylo,O. 2012. Examining the Planning and Management of Principal Succession. Journal of Educational Administration. 50 (2): 136 -147. 